\title{
United States - Continued Existence and Application of Zeroing Methodology: the end of Zeroing?
}

\author{
THOMAS J. PRUSA * \\ Rutgers University and NBER \\ EDWIN VERMULST** \\ Vermulst, Verhaeghe, Graafsma \& Bronckers
}

\begin{abstract}
This is the eighth Appellate Body Report in which some aspect of zeroing was adjudicated. As in the prior cases, the $\mathrm{AB}$ again found the US practice inconsistent with several aspects of the Anti-Dumping Agreement. The novelty in this dispute was the EC attempt to broaden the concept of what constitutes an appealable measure. The EC challenged whether a WTO decision regarding zeroing could apply to subsequent proceedings that might modify duty levels and asked the $\mathrm{AB}$ to decide whether the United States' continued use of zeroing in the context of a given case was consistent with WTO obligations. The $\mathrm{AB}$ stated that in its attempt to bring an effective resolution to the zeroing issue, the EC is entitled to frame the subject of its challenge in such a way as to bring the ongoing use of the zeroing methodology in these cases, under the scrutiny of WTO dispute settlement. The AB then cautiously applied the new perspective to US zeroing practice.
\end{abstract}

\section{Introduction}

United States - Continued Existence and Application of Zeroing Methodology ${ }^{1}$ is yet another dispute related to the US practice of zeroing in anti-dumping proceedings. As is well known to anyone familiar with WTO Appellate Body disputes, zeroing is the single most litigated subject in the history of the WTO. Indeed, this is the eighth Appellate Body ( $\mathrm{AB})$ Report in which some aspect of zeroing was adjudicated. ${ }^{2}$

\footnotetext{
*Email: prusa@econ.rutgers.edu

**Email: edwin.vermulst@vvgb-law.com
}

The views expressed in this paper are those of the authors and all omissions and errors are also of the authors.

1 United States - Continued Existence and Application of Zeroing Methodology (WT/DS350/AB/R, 4 February 2009) [hereinafter: US-Continued Zeroing (EC)].

2 Previous cases in which the AB ruled concerning zeroing: (1) European Communities - AntiDumping Duties on Imports of Cotton-Type Bed Linen from India, WT/DS141/AB/R of 1 March 2001 [EC-Bed Linen]; (2) United States - Sunset Review of Anti-Dumping Duties on Corrosion-Resistant 
On 2 October 2006, the EC requested consultations with regard to zeroing in certain specified anti-dumping (AD) measures. As has been the case for every dispute involving zeroing, consultations proved fruitless and on 10 May 2007 the EC requested the establishment of a Panel. The Panel issued its Report in 1 October 2008. As in several prior disputes, the Panel Report reflected some ambiguity regarding the WTO consistency of zeroing. ${ }^{3}$ Both parties appealed certain aspects of the Panel decisions. The AB issued its report on 2 February 2009. And, as it had done in every prior case involving zeroing, the AB's rulings were unambiguous - it upheld all Panel findings that zeroing was inconsistent with the WTO AntiDumping Agreement (ADA) and generally overturned the Panel's findings that ruled against the EC's claims against zeroing.

In many respects, this case seems very similar to previous complaints about the US practice of zeroing. The dispute concerns EC claims related to the use of zeroing in anti-dumping proceedings carried out by the US Department of Commerce. In this case, the EC challenged 'the specific instances of application of what it describes as the "zeroing methodology" in 4 anti-dumping investigations, 37 periodic reviews and 11 sunset reviews'. ${ }^{4}$ With respect to these specific 52 claims, we have little to add to the already voluminous literature critiquing the AB's approach toward zeroing. ${ }^{5}$ We agree with the legal-justification logic behind the AB's decisions - given that this case largely follows the script developed in prior

Carbon Steel Flat Products from Japan, WT/DS244/AB/R of 9 January 2004; (3) United States - Final Dumping Determination on Softwood Lumber from Canada, WT/DS264/AB/R of 11 August 2004 [US-Softwood Lumber V]; (4) United States-Laws, Regulations and Methodology for Calculating Dumping Margins (Zeroing), WT/DS294/AB/R of 18 April 2006 [US-Zeroing (EC)]; (5) United States - Final Dumping Determination on Softwood Lumber from Canada, WT/DS264/AB/RW of 15 August 2006 [US-Softwood Lumber V (compliance)]; (6) United States-Measures Relating to Zeroing and Sunset Reviews, WT/DS322/AB/R of 9 January 2007 [US-Zeroing (Japan)]; (7) United States - Final Anti-dumping Measures on Stainless Steel from Mexico, WT/DS344/AB/R of 30 April 2008 [US-Stainless Steel (Mexico)]. In addition to these AB reports, zeroing was discussed by Panels in: (1) EC - Anti-Dumping Duties on Malleable Cast Iron Tube or Pipe Fittings from Brazil, WT/DS219/R of 7 March 2003; (2) United States - Anti-Dumping Measure on Shrimp from Ecuador, WT/DS335/R of 30 January 2007; and (3) United States - Measures Relating to Shrimp from Thailand, WT/DS343/R of 29 February 2008.

3 In US-Stainless Steel (Mexico) and US-Zeroing (Japan), the Panels ruled that zeroing in original investigations was inconsistent, but zeroing in review proceedings was consistent. In both cases, the $\mathrm{AB}$ overturned the Panel with respect to zeroing in review proceedings.

4 US-Continued Zeroing (EC), Panel, para. 2.1.

5 See, e.g., Merit E. Janow and Robert W. Staiger (2003), 'EC - Bed Linen European Communities Anti-Dumping Duties on Imports of Cotton-Type Bed Linen from India', in Henrik Horn and Petros C. Mavroidis (eds.), The WTO Case Law of 2001, Cambridge: Cambridge University Press; Gene M. Grossman and Alan O. Sykes (2006), 'European Communities - Anti-Dumping Duties on Imports of Cotton-Type Bed Linen from India: Recourse to Article 21.5 of the DSU by India', in Henrik Horn and Petros C. Mavroidis (eds.), The WTO Case Law of 2003, Cambridge: Cambridge University Press; Chad P. Bown and Alan O. Sykes (2008), 'The Zeroing Issue: A Critical Analysis of Softwood V', World Trade Review, 7(1): 121-142; Thomas J. Prusa and Edwin Vermulst (2009), 'A One-Two Punch on Zeroing: US-Zeroing (EC) and US-Zeroing (Japan)', World Trade Review, 8(1): 187-241; Meredith Crowley and Robert Howse (2010), 'US-Stainless Steel (Mexico)', World Trade Review, 9(1): 117-150. 
cases, this should not be surprising. Further, as we have argued in the past, we also believe that standard economic statistical inference methods demand that all transactions be included in a 'fair' comparison. ${ }^{\mathbf{6}}$

What gives this case gravitas is a new type of zeroing challenge - in this case the $\mathrm{EC}$ asked the $\mathrm{AB}$ to comment on what constitutes an appealable measure and whether a WTO decision regarding zeroing could apply to subsequent proceedings that might modify duty levels. Given the United States' refusal to stop zeroing despite numerous WTO decisions, it is easy to assume that the word 'continued' in the case title is used in the same way Hollywood uses numerals to denote sequels to blockbuster movies - in one year the challenge might involve zeroing with respect to steel bars, and the next-year challenge might involve zeroing with respect to pasta. Given the breadth of the EC products under US AD orders, we know of no Hollywood movie franchise that has the potential to match the number of potential EC zeroing disputes!

In this case, however, the term 'continued' is used in a different sense. In this case, the EC asked the AB to decide whether the United States' continued use of zeroing in the context of a given case was consistent with WTO obligations.

A bit of perspective is needed to understand the nature of the EC's claim. First, the United States has a retrospective duty-assessment system. In the retrospective system used by the United States, the dumping margin calculated in the initial investigation only establishes the deposit rate. The actual dumping margin is established during annual administrative reviews, although they often occur less frequently in practice. Second, the United States has responded to previous AB determinations by no longer zeroing in original investigations. The United States still contends, however, that the WTO ADA allows zeroing during administrative reviews. Given that the actual collected margins are determined during the administrative-review phase, the United States still practices zeroing when it really matters. Third, even if the $\mathrm{AB}$ finds zeroing as practiced in a review for a specific product and supplier is inconsistent, the United States' current policy is that the $\mathrm{AB}$ decision applies only to that particular measure. If the US Department of Commerce does a new administrative review, then the onus is back on the EC (or any other affected member country) to file another dispute with regards to that new review. The current US practice creates a 'cat and mouse' game with its trading partner. The measure currently in effect is almost always different from the one that is being challenged at the WTO.

The EC submission included claims requesting the $\mathrm{AB}$ to find that the US ongoing or continued zeroing is inconsistent with the ADA. For all intents and purposes, the meat of this dispute is this continued-zeroing claim.

6 Prusa and Vermulst (2009), 'A One-Two Punch on Zeroing: US-Zeroing (EC) and US-Zeroing (Japan)'. 


\section{What measures can be challenged?}

Beyond the specific instances of zeroing enumerated in the aforementioned 52 claims, the EC also challenged the continued application by the United States of anti-dumping duties resulting from the anti-dumping orders enumerated in 18 cases, as calculated or maintained in place at a level in excess of the margin of dumping that in the EC's view would have resulted from the correct application of the relevant provisions of the Anti-Dumping Agreement. ${ }^{7}$ These 18 alternative claims are quite different from the zeroing claims made in previous disputes. The Panel's discussion and analysis of these claims clearly suggests a struggle to properly fit these claims into WTO dispute rules. Without any prior jurisprudence, the Panel floundered as it sought to put this new and broadened sense of 'measure' into proper legal context.

In an Annex to the request for establishment of the Panel (REP), the EC numbered the 18 orders from I to XVIII and the administrative determinations from 1 to 52 . In Table 1, we provide an excerpt from the Annex to the EC's REP in an attempt to clarify the relationship between the two concepts. In this example, the EC challenged the continued application of zeroing in 'Case XIII' Certain Pasta from Italy in general, as well as various types of zeroing applied in four periodic reviews and one expiry review conducted in the framework of this case.

The motivation for the EC's request for the WTO AB to decide on zeroing in the context of a case rather than just for each separate dumping calculation is understandable. If member countries can only challenge each application of zeroing in a specific determination, there is the prospect of a never-ending cycle of ineffective complaints (the cat-and-mouse game alluded to above). By the time the EC (or any other member country) prevails at the WTO on a zeroing complaint, the challenged determination almost surely has been replaced by a new administrativereview determination, which in effect makes the sanctioned zeroing measure moot. In turn, this means the new measure would need to be challenged again. The combination of the US system of annual retrospective reviews, its continued use of zeroing in administrative reviews, and the two + year duration of a WTO dispute mean the WTO AB rulings are largely meaningless.

In our view, the question of what is a measure is the single most compelling aspect of this dispute.

\section{Commentary}

A significant part of this dispute and the accompanying $\mathrm{AB}$ report concerns what by now could be called standard zeroing complaints: the EC made claims against 52 specific instances of zeroing. We have previously stated our legal and economic perspective on the practice of zeroing and we see no reason to repeat those

7 US-Continued Zeroing (EC), AB, para. 1. 
Table 1. Excerpt from annex to EC’s Panel request

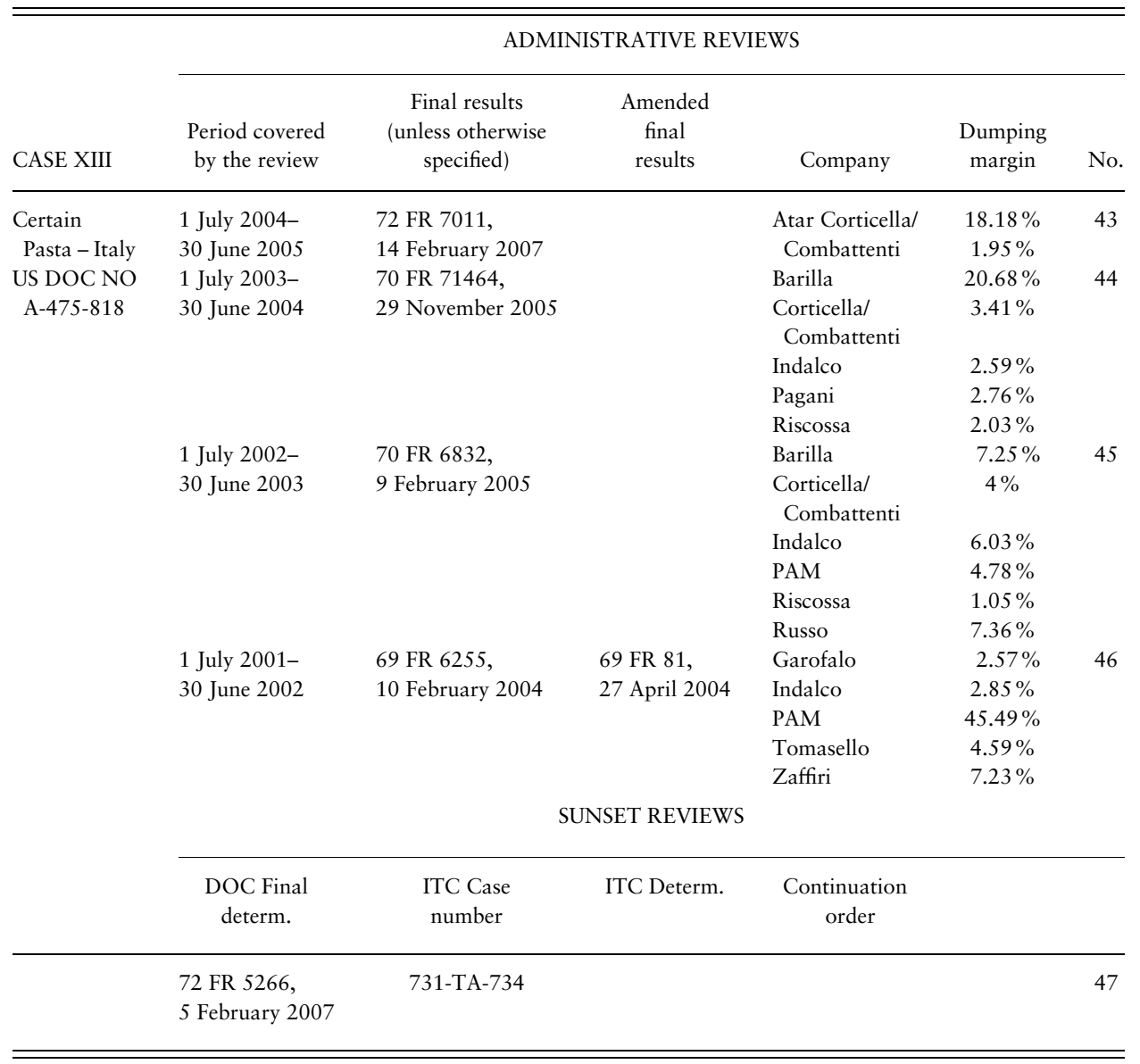

arguments here. For those interested in details, we include a summary table of the Panel and $\mathrm{AB}$ decisions in an appendix.

Instead, we proceed by discussing several other issues that emerged in the dispute. Two are particularly significant. The first involves the issue of what constitutes a zeroing measure. To our knowledge, this case is the first time it has surfaced in the zeroing context. The second issue concerns the role of precedent; this was also discussed extensively in US-Stainless Steel (Mexico). The other issues likely have less consequence for future $\mathrm{AB}$ jurisprudence but deserve some brief comments.

\section{1 'Cases' versus 'proceedings'}

In its request for establishment of the Panel (REP) $)^{8}$ the EC had made a distinction between the (continued) application of specific anti-dumping duties resulting from

8 United States-Continued Existence and Application of Zeroing Methodology, request for the establishment of a Panel by the European Communities, WT/DS350/6 (11 May 2007). 
18 anti-dumping orders and-more specifically - administrative determinations pertaining to these 18 orders in which it considered that the US authorities had applied zeroing.

The Panel had found that the EC had failed to identify in the REP the specific measures at issue within the meaning of Article 6.2 $\mathrm{DSU}^{9}$ with respect to the (continued) application of the 18 orders. The Panel had considered that, in this regard, the REP had not been specific enough and that the (continued) application did not represent a measure in and of itself. On appeal, the EC explained that its objective in challenging the 18 orders as measures was to 'apprehend the root of the WTO inconsistency as it relates to a particular anti-dumping duty'. ${ }^{10}$

According to the consistent case law of the AB, it has to be clear from the REP which measures are challenged because the REP establishes both the jurisdiction of the Panel and notifies the respondent and possible third parties of the content and the parameters of the dispute. ${ }^{11}$ Where jurisdictional objections are raised, as was the case here, the Panel must examine whether the REP, read as a whole, on its face complies with these requirements.

The AB considered that the REP linked (1) the duties resulting from the 18 antidumping duty orders, (2) their most recent periodic or sunset review, and (3) the use of the zeroing methodology, and that, consequently, the United States could reasonably have expected to understand the nature of the challenges. Therefore, the $\mathrm{AB}$ concluded that the REP was specific enough. The AB rejected that the Panel examination at this stage would need to encompass a substantive assessment of whether a claimed measure constituted a challengeable measure. Such analysis comes into play only in the course of a Panel proceeding and is not a prerequisite for the establishment of the Panel. ${ }^{12}$

Nor did the AB consider relevant the Panel's argument that to accept the EC's claims with respect to the continued application of the 18 orders would amount to an acceptance of prospective remedies. On the contrary, the AB considered it logical in light of the nature of the EC's challenge of ongoing measures that the remedy sought was prospective. Furthermore, prospective remedies were common in other areas of WTO dispute settlement as well, for example in case of 'as such' claims or claims related to recurring subsidies. ${ }^{13}$

The $\mathrm{AB}$ then proceeded to examine whether these measures were susceptible to a WTO challenge. It reiterated that any act or omission attributable to a WTO

9 Article 6.2 DSU provides, in relevant part, that the REP shall identify the specific measure at issue and provide a brief summary of the legal basis of the complaint sufficient to present the problem clearly. These two elements together constitute the 'matter' that forms the basis for the terms of reference of the Panel, see AB Report, para. 160.

10 US-Continued Zeroing (EC), AB, para. 16.

11 Ibid., para. 161.

12 Ibid., para. 169.

13 Ibid., para. 171. 
Table 2. Decisions regarding continued application of zeroing in $18 \mathrm{AD}$ cases

\begin{tabular}{|c|c|c|}
\hline Panel & $\begin{array}{l}\text { Decision } \\
\text { Rejected EC claims }\end{array}$ & $\begin{array}{c}\text { Rationale } \\
\text { Lack of specificity makes claims 'outside } \\
\text { terms of reference' }\end{array}$ \\
\hline $\mathrm{AB}$ & $\begin{array}{l}\text { Reversed Panel; completed analysis } \\
\text { - } 4 \text { cases inconsistent } \\
\text { - } 14 \text { cases excluded }\end{array}$ & $\begin{array}{l}\text { Continued use of zeroing within a case } \\
\text { can be challenged } \\
\text { - ADA Article 9.3; GATT Article VI.2; } \\
\text { ADA Article } 11.3 \\
\text { - Repeated instances of zeroing were not } \\
\text { presented ( } 6 \text { cases) } \\
\text { - Partial evidence inconclusive } \\
\text { (8 cases) }\end{array}$ \\
\hline
\end{tabular}

member may qualify as a measure ${ }^{14}$ and considered the distinction between 'as such' and 'as applied' claims not relevant for the dispute at issue. In other words, the fact that the continued-application claims of the EC fit in neither of the two categories had no bearing on their ability to be challenged..$^{15}$ The $\mathrm{AB}$ considered that ongoing conduct could form the basis for a WTO challenge and that, in fact, the EC 'in seeking an effective resolution ... is entitled to frame the subject of its challenge in such a way as to bring the ongoing conduct, regarding the use of the zeroing methodology in these 18 cases, under the scrutiny of WTO dispute settlement'. ${ }^{16}$

The $\mathrm{AB}$ then completed the analysis in the cases where it considered that there was sufficient factual evidence available to conclude that zeroing would likely continue to be applied in successive future determinations. The results regarding these cases are given in Table 2 . The $\mathrm{AB}$ proceeded very cautiously at this point, stating 'we must ascertain whether the factual findings made by the Panel and undisputed facts in the record show that the zeroing methodology has been used repeatedly in successive proceedings, in each of the 18 cases, by which the duties are maintained'. ${ }^{17}$

In four of the 18 cases, the $\mathrm{AB}$ found a 'density of factual findings ... regarding the continued use of the zeroing methodology in a string of successive proceedings pertaining to the same anti-dumping duty order', sufficient to provide a basis for concluding that 'the zeroing methodology would likely continue to be applied in successive proceedings whereby the duties in these four cases are maintained'.$^{18}$

Six of the cases concerned only a single proceeding in each case where duties were applied with zeroing. The $\mathrm{AB}$ did not find the single instance sufficient to

14 Ibid., para. 176.

15 Ibid., paras. $178-180$.

16 Ibid., para. 181.

17 Ibid., paras. 187-189.

18 Ibid., paras. 191-192. 
conclude ongoing conduct in those cases. ${ }^{19}$ In the other eight cases, the AB found the Panel's factual findings inconclusive with respect to the use of zeroing in successive proceedings - either evidence was missing or incomplete from the record. ${ }^{20}$ As a result, the $\mathrm{AB}$ opted to proceed extremely cautiously and declared the evidence was inconclusive to render a decision.

We believe that the AB's adoption of a broad definition of 'measures' so as to encompass ongoing illegal conduct was the only way in which the ongoing cat-and-mouse game could effectively be sanctioned. As a matter of law, we see no problem with the AB's broad definition of a 'measure'. In anti-dumping proceedings, the basic calculation methodologies are often established in the course of the original investigation. In subsequent review investigations, the same methodologies are then applied. In the US retrospective system, the original investigation culminates in the publication of the anti-dumping duty order, for example, on pasta. As of this moment, an anti-dumping measure applies to pasta. The fact that, in the US system, the actual rate of the duty to be paid is only determined subsequently in the course of the annual reviews seems irrelevant.

We do feel that the terminology used by not only the $\mathrm{AB}$ and the Panel, but also by the parties remains confusing. While the ADA is not clear either, one could envisage a relatively simple distinction between a 'proceeding' and an 'investigation'. Under this terminology, in the example above the proceeding would be 'Certain Pasta from Italy'. A proceeding continues as long as it is not terminated. In the course of a proceeding, various investigations may be conducted, starting with the original Article 5 investigation. Assuming that the initial Article 5 investigation leads to the imposition of anti-dumping measures, such measures may then be subject to, for example, periodic review investigations (in the US retrospective system), interim, expiry, and newcomer review investigations, and anticircumvention and (in the EC) anti-absorption investigations. Depending on the type of investigation, the measure, as originally imposed in the Article 5 investigation, may then be confirmed, amended, or terminated, which ends the investigation. However, as long as the measure is not terminated in the course of a review investigation, the proceeding continues.

\subsection{The role of precedent: simple zeroing as applied in 29 periodic reviews}

The Panel was well aware that the prior AB Reports had consistently reversed the findings in prior Panel Reports that simple zeroing in periodic reviews is not WTOinconsistent. Seemingly with great reluctance, the Panel acknowledged it needed to consider the role of jurisprudence in the WTO dispute-settlement system, in particular the 'role of adopted Appellate Body reports'. ${ }^{21}$ Particular weight was given

19 Ibid., para. 193.

20 Ibid., para. 194.

21 US-Continued Zeroing (EC), Panel, para. 7.170. 
to the AB Report in US-Stainless Steel (Mexico $)^{22}$ wherein the Panel did not follow prior AB Reports and was subsequently overturned and rebuked by the AB.

In light of the Stainless Steel Report, the Panel agreed with the view that 'security and predictability in the dispute settlement system per se is a purpose served by the development of a consistent body of case law based on panels following the reasoning of adopted Appellate Body reports'. ${ }^{23}$ The Panel then stated that (1) 'it is obviously incumbent upon any panel to consider prior adopted Appellate Body reports, as well as adopted panel reports, and adopted GATT panel reports, in undertaking the objective assessment required by Article 11', ${ }^{24}$ and (2) 'prior adopted reports form part of the GATT/WTO acquis, and, as stated by the Appellate Body, create legitimate expectations among WTO Members, and, therefore, should be taken into account where they are relevant' ${ }^{25}$

However, the Panel was not about to go quietly into the night. Countering the above discussion, the Panel stated that it did 'not consider that the development of binding jurisprudence is a contemplated element to enable the dispute settlement system to provide security and predictability to the multilateral trading system ${ }^{, 26}$ and that 'a panel cannot simply follow the adopted report of another panel, or of the Appellate Body, without careful consideration of the facts and arguments made by the parties in the dispute before it' ${ }^{27}$

In effect, the Panel is saying that it would be perfectly legitimate for it to deviate from the AB's jurisprudence. However, since the AB would almost surely overrule the Panel, the only consequence of such a decision would be to delay a final settlement of the dispute, which thus would be at odds with the goal of promptly settling the dispute. One gets the very real sense that the Panel cannot accept that the $\mathrm{AB}$ has some superior authority in its role as interpreter of the law.

Ultimately, a clearly conflicted Panel grudgingly accepted the findings of the AB Report in US-Stainless Steel (Mexico $)^{28}$ and accordingly found that the United States' use of simple zeroing in 29 periodic reviews had violated Article 9.3 ADA and Article VI:2 GATT 1994.

On appeal, the United States essentially rehashed its traditional argumentation that simple zeroing in periodic reviews constitutes a permissible interpretation of the ADA.

The AB started its analysis with examination of Article 17(6)(ii) and reiterated that, on the basis of the first sentence, Panels adjudicating disputes under the ADA

22 US-Stainless Steel (Mexico), discussed in Crowley and Howse (2010), 'US-Stainless Steel (Mexico)'.

23 US-Continued Zeroing (EC), Panel, para. 7.179.

24 Ibid.

25 Ibid.

26 Ibid.

27 Ibid., para. 7.180.

28 US-Stainless Steel (Mexico), discussed in Crowley and Howse (2010), 'US-Stainless Steel (Mexico)'. 
must apply Articles 31 and 32 of the Vienna Convention on the Law of Treaties (VCLT):

The principles of interpretation that are set out in Articles 31 and 32 are to be followed in a holistic fashion. The interpretative exercise is engaged so as to yield an interpretation that is harmonious and coherent and fits comfortably in the treaty as a whole so as to render the treaty provision legally effective. A word or term may have more than one meaning or shade of meaning, but the identification of such meanings in isolation only commences the process of interpretation, it does not conclude it. ${ }^{29}$

The $A B$ then emphasized that the first and second sentence of Article 17(6)(ii) have to be applied sequentially, meaning that the second sentence ('more than one permissible interpretation') will need to be applied only if there is room for that after proper application of Articles 31 and 32 VCLT under the first sentence. On the other hand, these articles also apply to the interpretation of the second sentence itself, so that it cannot be interpreted in a manner which makes it redundant or which derogates from Articles 31 and 32. The AB considered that the second sentence therefore envisages the possibility that application of Articles 31 and 32 may give rise to an 'interpretative range'.

The AB then consecutively considered and rejected US arguments with respect to the concept of 'dumping' and 'margins of dumping' in the ADA, implications for importer-specific duty assessment in periodic reviews, discrimination between prospective normal value systems and the US retrospective duty-assessment system, 'mathematical equivalence' and the historical background of the dumping concept. It concluded that zeroing is inconsistent with Article 9.3 ADA on the basis of the application of Article 17(6)(ii), first sentence. The second sentence therefore did not come into play:

A holding that zeroing is also consistent with Article 9.3 would be flatly contradictory. Such contradiction would be repugnant to the customary rules of treaty interpretation ... Consequently, it is not a permissible interpretation. ${ }^{30}$

In a concurring opinion, one Member of the Division further noted that:

The range of meanings that may constitute a permissible interpretation does not encompass meanings of such wide variability, and even contradiction, so as to accommodate the two rival interpretations. One must prevail. The Appellate Body has decided the matter. At a point in every debate, there comes a time when it is more important for the system of dispute resolution to have a definitive outcome, than further to pick over the entrails of battles past. With respect to zeroing, that time has come. ${ }^{31}$

29 US-Continued Zeroing (EC), AB, para. 268.

30 Ibid., para. 317.

31 Ibid., para. 312. 
In this context, it is also noted that in one of its conditional appeals, the EC had-somewhat gratuitously - requested that, if the Panel Report were to be construed as finding that a Panel can invoke 'cogent reasons' for departing from previous $\mathrm{AB}$ rulings on the same issue of legal interpretation, the $\mathrm{AB}$ modify or reverse such a Panel finding. ${ }^{32}$ In the view of the $\mathrm{EC}$, only the $\mathrm{AB}$ itself should have the power to invoke such cogent reasons.

The AB considered that it did not have to rule on the conditional appeal because, although the Panel Report was at places ambiguous, in the end the Panel followed the previous $\mathrm{AB}$ Reports and therefore appeared 'to have acceded to the hierarchical structure contemplated in the DSU' ${ }^{33}$

Crowley and Howse (2010) offer an excellent discussion of the role of precedent at the WTO. ${ }^{34}$ In particular, they argue that while the original agreement may contain vague language (because it is impossible for negotiators to include all possible developments in the text), economic efficiency can be enhanced with specificity that comes from legal challenges. Not only does precedent reduce uncertainty but it also can induce welfare-enhancing changes in behavior. The cost of precedent is the loss of flexibility. We agree with Crowley and Howse's analysis and also with their conclusion that, in the case of zeroing, the benefits of precedent outweigh the costs.

We find the Panel's discussion has again added unneeded ambiguity to the zeroing saga. The Panel argues that it must evaluate each case on its own merits. But this 'evaluation' need not involve the issue of whether the practice is consistent. The Panel's discussion misrepresents the AB's basis for finding zeroing inconsistent and also suggests that the practice of zeroing varies from case to case. One can read the Panel Report and get the impression that zeroing is less like an explicit violation such as levying tariffs beyond bound rates and more akin to a phytosanitary dispute where (in most cases) the basis for the restriction must be carefully evaluated.

We entirely agree that the Panel must confirm that zeroing was conducted in each case. That being said, the United States has never provided evidence of any challenged measure where the zeroing methodology was not performed. The best the United States has ever argued is that zeroing might not affect the calculated duty for a particular set of pricing data, e.g. when the export price is always lower than the home-market price. While the Panel must conduct its review, it also must recognize that the zeroing method is a standard part of the computer code that the US Department of Commerce uses in every case.

Moreover, while we agree with the Panel's view that its finding that zeroing is permitted would simply delay a final settlement of the dispute (because the AB would surely overrule the Panel) and therefore is at odds with the goal of promptly

32 Ibid., para. 358.

33 Ibid., para. 365.

34 Crowley and Howse (2010), 'US-Stainless Steel (Mexico)'. 
settling the dispute, we consider there are additional costs to such an opinion. To begin with, it undermines the legitimacy of the prior AB decisions. Ambiguity in the face of clear $\mathrm{AB}$ language to the contrary fosters ongoing disputes over zeroing. The United States can quote Panel decisions that support the current practice.

In addition, the Panel's discussion suggests that the basis for the previous $A B$ decisions is something that it is not. The $\mathrm{AB}$ has not said that the inconsistency lies in a particular application; rather the $\mathrm{AB}$ has repeatedly said that zeroing is inconsistent with Article 2.4.2 AD Agreement-it violates the notion of 'fair comparison'.

We are also troubled by what the lack of consistent $\mathrm{AB}$ decisionmaking would mean for the two important GATT/WTO principles: predictability and nondiscrimination. Said differently, the Panel's suggestion that the consistency of zeroing might vary from case to case would create a serious time-consistency problem for WTO members. Under the Panel's view, it is quite possible that the United States could practice zeroing when computing margins for a pasta producer from Italy but be prohibited from using zeroing when computing margins for a pasta producer from Japan. As a result, two firms with identical home and export prices could have dramatically different margins. Furthermore, not every WTO member may be willing to spend money and/or political capital in challenging the United States on zeroing in the WTO.

\subsection{Challenging preliminary determinations}

Four of the 52 administrative determinations challenged by the EC were preliminary determinations in periodic or sunset reviews. The Panel had considered these claims to be outside its terms of reference because the EC had not claimed a violation of Article 7.1 ADA while Article 17.4 ADA provides that a provisional antidumping measure may be challenged only if it has a significant impact and if the complainant considers that the provisional measure was taken contrary to the provisions of Article 7.1.35

The EC appealed this decision, arguing that it had not challenged preliminary determinations within the meaning of Article 7.1 ADA. The AB agreed with the EC's contention. The AB considered Article 7 only applicable to provisional measures taken in the context of an original Article 5 investigation and therefore overturned the Panel's finding.

However, the $\mathrm{AB}$ declined to complete the analysis on the grounds that the two preliminary DOC determinations could still be modified by the final results while the other two final DOC determinations had still been pending before the USITC at the time the Panel was established. ${ }^{36}$ The fact that one of these latter two cases 
was ultimately revoked ${ }^{37}$ further convinced the $\mathrm{AB}$ that the EC's challenge was premature.

The AB's refusal to complete the analysis seems based on the logic that the various preparatory steps in an investigation are not final yet and may still be changed at the definitive stage. While the $\mathrm{AB}$ rightly concluded that the EU's challenge was not based on Article 7.1 ADA, in effect its refusal to complete the analysis would appear to indicate that it is even harder to challenge a preliminary review determination than it would be to challenge a preliminary determination in an original investigation based on Article 7.1.

\subsection{Linkage between request for consultations and REP}

During the Panel proceeding, the United States had requested a preliminary ruling that 14 of the 52 determinations listed in the annex to the REP were outside the Panel's terms of reference because they had not been identified in the request for consultations (RfC). The Panel had rejected this request on the ground that the $\mathrm{RfC}$ and the REP covered the same subject matter and the same dispute.

The AB upheld the Panel findings on the basis of its previous case law that Articles 4 and 6 DSU do not require a precise and exact identity between the specific measures that were the subject of the consultations and those identified in the REP, as long as the REP does not expand the scope of the dispute. ${ }^{38}$

The $\mathrm{AB}$ also found as a factual matter that the EC had identified the 18 cases in the RfC. ${ }^{39}$

The AB's findings on this issue confirm that there does not necessarily need to be complete synchronicity between the contents of the RfC and the REP, as long as the REP does not broaden the scope of the dispute. As consultations are merely a preparatory, albeit mandatory, step in the WTO dispute-settlement process, and amicable settlement as a result of consultations is relatively rare, the AB's relatively relaxed position on this procedural issue seems justified.

\subsection{Mathematical equivalence}

One ongoing argument made by the United States justifying zeroing is that prohibiting zeroing implies that the two methods for calculating margins in Article 2.4.2, weighted average-weighted average (WW) and weighted average-transaction (WT), yield identical results. As a result, according to the United States prohibiting zeroing makes one of the methods redundant and hence meaningless. ${ }^{40}$ By inference, this means that zeroing was anticipated by the negotiating parties, for what other reason would have the ADA mentioned two methods that yield identical results?

\footnotetext{
37 The revocation was the result of a negative ITC sunset injury determination.

38 US-Continued Zeroing (EC), AB, paras. 222 and 235.

39 Ibid., paras. 237-241.

40 US-Continued Zeroing (EC), Panel, para. 7.125.
} 
The United States' argument has never garnered any support at the AB. The AB has repeatedly stated that one method of calculation cannot be used to interpret other methodologies. In addition, the $\mathrm{AB}$ has questioned the generality of the mathematical equivalence.

Previously we have discussed the mathematical equivalent issue. ${ }^{41} \mathrm{We}$ mention two important results. First, as we explain, the two methods do produce equivalent margins without zeroing under certain circumstances. Namely, all transactions must be used to compute the weighted-average price. While that sounds simple enough, the United States generally does not calculate the WT margins this way. Rather, the United States will divide the transactions by time period or exporter and then calculate the comparison margin. As shown in Prusa and Vermulst (2009), this can produce different margins.

Second, we are troubled by the argument that the WTO AB should not restrict zeroing if doing so means two methods produce identical outcomes. According to the United States, why would the treaty mention two methods for calculating margins if they produce the same margin? From an economic perspective, the US argument is problematic. There are many policies that produce identical results; some are allowed under the WTO, some are not. Does the United States' 'potentially equivalent' argument apply to all such policies? Tariffs and quotas can have the exact same impact on exporters. One of the more celebrated theorems in international economics, the Lerner symmetry theorem, states that an ad valorem tariff will have the same effect as an export tax. Tariffs are subject to countless WTO rules but export taxes are permitted. It is the United States' position that the possible equivalence between export taxes and tariffs means the WTO should not negotiate reductions to tariffs. What about ad valorem and specific tariffs? They too can be designed to have the same impact. Does the United States believe that negotiators did not know of their equivalence during the Uruguay Round talks?

If the AB upheld the United States' position that the potential equivalence could not have been what negotiators meant, then all sorts of WTO provisions could be potentially challenged. We do believe this would neither be good for the system nor what negotiators actually intended. Alternative methods can be mentioned in the text to give countries flexibility in implementing policy. In cases with tens of thousands of individual transactions (e.g., semiconductors) one method might be preferred, while in a case with only a handful of sales (e.g., large printing presses) another method might be preferred. We believe this is why the negotiators offered several methods for calculating margins.

\subsection{Evidence}

The Panel had found that the EC had not been able to show that the United States had actually zeroed in seven of the 37 challenged periodic reviews. The main

41 Prusa and Vermulst (2009), 'A One-Two Punch on Zeroing: US-Zeroing (EC) and US-Zeroing (Japan)'. 
reason was that in these seven reviews, the United States had not explicitly mentioned that it had used zeroing. However, the EC had submitted various types of evidence to the Panel which, in its view, established that the DOC had employed zeroing. The Panel had examined this evidence type by type and determined that none of them conclusively showed that zeroing had been used. On appeal, the EC claimed that the Panel had not made an objective assessment of the matter before it, including an objective assessment of the facts of the case, within the meaning of Article 11 DSU.

The AB noted in general terms that a Panel has to 'consider evidence before it in its totality, which includes consideration of submitted evidence in relation to other evidence'. ${ }^{42}$ The AB considered that, in this case, the type-by-type approach taken by the Panel failed to consider the evidence in its totality. The AB further considered that the Panel had failed to assess the probative value of individual pieces of evidence in relation to other evidence. ${ }^{43}$ Last, the AB found that the Panel's insistence on authenticated DOC margin-calculation programs to show the use of zeroing (rather than printed copies provided by the EC), amounted to a failure to make an objective assessment.

Under Article 13, DSU Panels have the right to seek information from any individual or body that it deems appropriate. During the Panel proceeding, the EC had noted that 'should the Panel consider further corroboration appropriate, the Panel should request the United States to provide copies of the detailed margin calculations for each of the seven administrative reviews at issue'. ${ }^{44}$ However, the Panel had declined to do so. The AB did not find fault with the Panel's refusal to do so as such, because the Panel has discretion to exercise its Article 13 right. However, the $\mathrm{AB}$ emphasized that Article 13 and Article 11 are linked and that Panels have an important investigative function to request information, for example, to evaluate evidence already before it. In light of the importance that the Panel had attached to the evidentiary value of authenticated DOC margincalculation programs, the Panel had not taken the necessary steps to elicit such information. ${ }^{45}$

The $\mathrm{AB}$ then tried to complete the analysis on the basis of the factual findings and uncontested facts on the Panel record and found that it could do so for five of the seven periodic reviews. By looking at the totality of the evidence and effectively taking into account the printouts of the DOC margin calculations provided by the EC to the Panel, the AB concluded that the DOC had applied zeroing in five of the seven reviews. ${ }^{46}$

42 US-Continued Zeroing (EC), AB, para. 331.

43 Ibid., paras. 336-338.

44 Ibid., para. 344.

45 Ibid., paras. 345-347.

46 Ibid., paras. 349-357. 


\section{Concluding comments}

All in all, the AB's ruling in this case is a decisive rejection of the US practice. When considered alongside two other very broad rulings, US-Zeroing $(E C)^{47}$ and US-Zeroing (Japan), ${ }^{48}$ it is becoming increasingly unlikely that the United States can ever succeed in a WTO dispute involving zeroing.

The most significant issue in the case involved the concept of a 'measure'. The standard classification of claims as either 'as such' (measures of general and prospective application) or 'as applied' (acts that apply to specific situations) was not adequate in this case. While the Panel struggled with the EC's identification of the precise content of the measures, the $\mathrm{AB}$ argued that the 'as such-as applied' distinction was only an 'analytical tool to facilitate the understanding of the nature of a measure at issue" 49 and did 'not define exhaustively the types of measures that may be subject to challenge in WTO dispute settlement ${ }^{\text {' }}{ }^{50}$ In this case, the AB stated that 'the measures at issue consist of the use of the zeroing methodology in a string of connected and sequential determinations' ${ }^{51}$ and it saw "no reason to exclude ongoing conduct that consists of the use of the zeroing methodology from challenge in WTO dispute settlement'. ${ }^{52}$

With this decision, the ability for the United States to continually use successive administrative reviews to avoid sanctionable violations appears to have come to an end. The question remains whether this will force the United States to alter its zeroing policy.

47 US-Zeroing (EC) (also WT/DS294/AB/Corr.1, 20 August 2007; WT/DS294/R, 31 October 2005). 48 US-Zeroing (Japan)] (also WT/DS322/R, 20 September 2006).

49 US-Continued Zeroing (EC), AB, para. 179.

50 Ibid.

51 Ibid., para. 181.

52 Ibid. 


\section{Appendix: Summary of Panel and AB Decisions regarding 52 specific instances of zeroing}

\begin{tabular}{|c|c|c|c|c|}
\hline \multirow{2}{*}{$\begin{array}{l}\text { Model Zeroing } \\
\text { in } 4 \text { original } \\
\text { investigations }\end{array}$} & \multicolumn{2}{|r|}{ Panel } & \multicolumn{2}{|c|}{$\mathrm{AB}$} \\
\hline & $\begin{array}{c}\text { Decision } \\
4 \text { inconsistent }\end{array}$ & $\begin{array}{c}\text { Rationale } \\
\text { ADA Article 2.4.2 }\end{array}$ & $\begin{array}{c}\text { Decision } \\
\text { US did not appeal }\end{array}$ & Rationale \\
\hline \multirow{3}{*}{$\begin{array}{l}\text { Simple Zeroing } \\
\text { in } 37 \text { periodic } \\
\text { reviews }\end{array}$} & 29 inconsistent & $\begin{array}{l}\text { ADA Article 9.3; } \\
\text { GATT Article VI.2 }\end{array}$ & Upheld & \\
\hline & $\begin{array}{l}7 \text { measures } \\
\text { excluded }\end{array}$ & $\begin{array}{l}\text { EC had not showed } \\
\text { zeroing had been } \\
\text { used }\end{array}$ & $\begin{array}{l}\text { Reversed Panel; } \\
\text { completed analysis } \\
\text { for } 5 \text { measures; } \\
5 \text { measures } \\
\text { inconsistent }\end{array}$ & $\begin{array}{r}\text { ADA Article } \\
\text { 9.3; GATT } \\
\text { Article VI.2 }\end{array}$ \\
\hline & $\begin{array}{l}1 \text { preliminary } \\
\text { measure } \\
\text { excluded }\end{array}$ & $\begin{array}{l}\text { 'outside terms of } \\
\text { reference' }\end{array}$ & $\begin{array}{l}\text { Reversed Panel's } \\
\text { basis for decision } \\
\text { but did not find } \\
\text { the measure } \\
\text { inconsistent }\end{array}$ & $\begin{array}{l}\text { EC challenge } \\
\text { 'premature' }\end{array}$ \\
\hline $\begin{array}{l}\text { Model Zeroing } \\
\text { in } 11 \text { sunset } \\
\text { reviews }\end{array}$ & $\begin{array}{l}8 \text { inconsistent } \\
3 \text { preliminary } \\
\text { measures } \\
\text { excluded }\end{array}$ & $\begin{array}{l}\text { ADA Article } 11.3 \\
\text { 'outside terms of } \\
\text { reference' }\end{array}$ & $\begin{array}{l}\text { Upheld } \\
\text { Reversed Panel's } \\
\text { basis for decision } \\
\text { but did not find } \\
\text { the measures } \\
\text { inconsistent }\end{array}$ & $\begin{array}{l}\text { EC challenge } \\
\text { 'premature' }\end{array}$ \\
\hline
\end{tabular}

